\title{
End-product control of enzymes of branched-chain amino acid biosynthesis in Streptomyces coelicolor
}

\author{
Chris A. Potter and Simon Baumberg \\ Author for correspondence: Simon Baumberg. Tel: +44113233 3080. Fax: +44 113244 1175. e-mail: \\ GENGSB@LEEDS.AC.LK
}

Department of Genetics, University of Leeds, Leeds LS2 9JT, UK

\begin{abstract}
In streptomycetes, the branched-chain amino acids leucine, isoleucine and valine may serve as precursors for commercially important polyketides, and it is of interest to investigate whether the availability of these amino acids affects the production of the secondary metabolites derived from them. This paper reports studies on end-product control in the model organism Streptomyces coelicolor of the enzymes acetohydroxy acid synthase (AHAS) and isopropylmalate synthase (IPMS), mediating steps in the pathways to isoleucine-valine and leucine respectively. Specific activities of both enzymes were similarly affected when minimal medium was supplemented with the amino acids singly or in combination. Isoleucine alone caused a 2- to 3-fold increase, while all three amino acids caused a 5- to 8-fold decrease. Growth of an ilv auxotroph in media with limiting isoleucine gave enzyme specific activities 4- to 6-fold higher than in unsupplemented minimal medium. Spontaneous mutants were obtained by growing $S$. coelicolor on minimal medium containing 4-azaleucine. At least four patterns of end-product control were found among the mutants, one of which showed high constitutive levels of both enzymes (7- and 15-fold above unsupplemented minimal medium values for AHAS and IPMS respectively). It is concluded that the variation in specific activities of the two enzymes under different physiological and genetic conditions spans a range of around 50 to 100, and that $S$. coelicolor has molecular mechanisms capable of producing this response.
\end{abstract}

Keywords: Streptomyces coelicolor, acetohydroxyacid synthase, isopropylmalate synthase, branched-chain amino acids, feedback gene regulation

\section{INTRODUCTION}

Amino acids are frequent secondary metabolite precursors in the streptomycetes. An important example is provided by the branched-chain aliphatic amino acids leucine, isoleucine and valine, which are catabolized via transamination and oxidation by a branched-chain $\alpha$-keto acid dehydrogenase to fatty acyl-CoAs (Reynolds et al., 1988; Vančura et al., 1988; Tang et al., 1994). These fatty acylCoAs are then able to participate with type I polyketide synthases in the formation of extended-chain products (Katz \& Donadio, 1993; Hutchinson \& Fujii, 1995). Control of the formation and catabolism of these amino acids is likely to be a significant factor in the production of commercially important secondary metabolites synthe-

Abbreviations: AHAS, acetohydroxy acid synthase; IPMS, isopropylmalate synthase. sized in this way, such as the avermectins and the macrolides erythromycin, spiramycin and tylosin. Most work to date has been on the characterization and control of activity and synthesis of the catabolic dehydrogenases (see Hutchinson et al., 1993; Lounès et al., 1995; Nguyen et al., 1995; Denoya et al., 1995; and references therein). Regulation of amino acid formation has, however, been little studied. It has been suggested (see Hood et al., 1992, for a review) that in streptomycetes gene expression in biosynthetic pathways, including those for amino acids, is less responsive to nutritional environment than in other, more rapidly growing, bacteria. In conformity with this generalization, Vančura et al. (1989) reported that activity of acetohydroxyacid synthase (AHAS), the first common enzyme of isoleucine and valine synthesis (Fig. 1) was induced 2.1-, 2.5-, and 2.4-fold in the tylosin producer Streptomyces fradiae in the presence of valine, valine + leucine, and valine + leucine + isoleucine, respectively, 


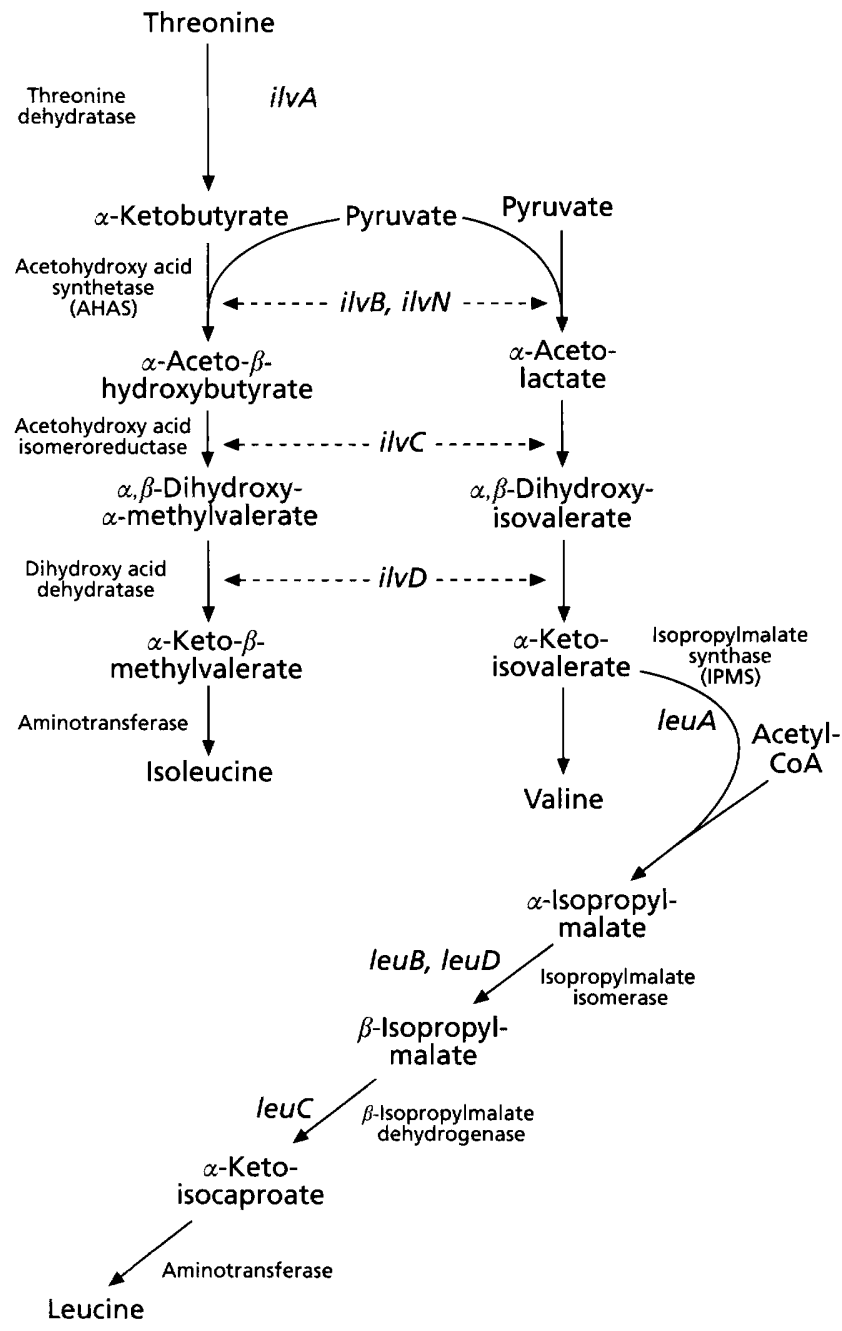

Fig. 1. Pathways, enzymes and genes of isoleucine/valine/ leucine biosynthesis. The genetic nomenclature follows that for B. subtilis (Fink, 1993).

and was repressed $1 \cdot 2$ - and $2 \cdot 0$-fold in the presence of leucine and isoleucine, respectively. There is little information on the streptomycete genes encoding these enzymes. We have reported (Hercomb et al., 1987) the cloning of a leuA gene, encoding isopropylmalate synthase (IPMS), the first enzyme of the leucine pathway, from a streptomycete isolate with weak cellulolytic activity provisionally identified as Streptomyces rochei. This gene has not been completely sequenced. The cloning and sequencing of leuC from the actinomycete Actinoplanes teichomyceticus has also been reported (Castelli et al., 1995).

We are interested in two linked questions: (i) does the regulation of formation of enzymes involved in biosynthesis of branched-chain amino acids in streptomycetes differ according to whether these amino acids are or are not secondary metabolite precursors? and (ii) can the regulation be manipulated to improve production of a secondary metabolite? We have begun by studying the regulatory phenotype of the model streptomycete $S$. coelicolor, though bearing in mind that its status in relation to question (i) above is unclear. This organism makes the polyketide actinorhodin, but this is a type II polyketide (Hopwood \& Khosla, 1992; Katz \& Donadio, 1993; Hutchinson \& Fujii, 1995) which uses exclusively acetylCoA rather than higher fatty acyl-CoAs. S. coelicolor may therefore represent streptomycetes not directly utilizing the branched-chain amino acids as secondary metabolite precursors. However, we note that exogenous valine stimulates production of actinorhodin by $S$. coelicolor, this effect possibly involving valine dehydrogenase (Tang \& Hutchinson, 1993).

We report here the effect of leucine, isoleucine and valine, supplied exogenously singly or in combination during growth, on the specific activities of AHAS and IPMS in mycelial extracts of $S$. coelicolor. We also describe experiments bearing on possible controls involving branchedchain amino acids on expression of the genes encoding these enzymes.

\section{METHODS}

Bacterial strains. S. coelicolor A3(2) prototroph D132 (SCP1 ${ }^{+}$ $\mathrm{SCP}^{+}$) and auxotroph 966 (ilv A1 phe $A 12$ str $A 1$ ) were kindly provided by the John Innes Institute. (Mutations affecting 'housekeeping' pathways in streptomycetes have not in general been ascribed to genes; 'ilv $A$ ' and ' $p h e A$ ' in the description of the latter strain do not therefore imply specific genes. Results reported below show that 966 is not deficient in AHAS.)

Media and growth conditions. Growth was in all cases at $30^{\circ} \mathrm{C}$. Spores of $S$. coelicolor strains grown on R 5 medium were obtained as described by Hopwood et al. (1985). To inoculate cultures, spores washed to remove glycerol were suspended in $0.05 \mathrm{mM}$ TES buffer, $\mathrm{pH} 8$, heated at $50^{\circ} \mathrm{C}$ for $10 \mathrm{~min}$, then rapidly cooled in ice water. The spores were then pregerminated for $2-3 \mathrm{~h}$ at $37^{\circ} \mathrm{C}$ according to the procedure of Hopwood et al. (1985). Pre-germinated spores were centrifuged, washed in TES buffer as before, resuspended in $4 \mathrm{ml}$ fresh TES buffer and then subjected to ultrasonic disintegration with a $15 \mathrm{~s}$ pulse at maximum amplitude in an MSE $100 \mathrm{~W}$ ultrasonic disintegrator to separate germ tubes. The treated spores were used as an inoculum to give a calculated $\mathrm{OD}_{640}$ of $0 \cdot 01-0 \cdot 015$. The growth medium was essentially the minimal medium of Doull \& Vining (1989), which contained MOPS $(100 \mathrm{mM})$ as buffer, glutamate $(50 \mathrm{mM})$ and glucose $(2.5 \%)$ as nitrogen and carbon sources respectively, and $10 \mathrm{mM}$ potassium phosphate, with in addition $1 \%(\mathrm{w} / \mathrm{v})$ carboxymethylcellulose (CMC) (Fluka, highly purified; ultra-high viscosity, such that a $2 \%$ aqueous solution has a viscosity of $\sim 15000 \mathrm{mPa} \mathrm{s}^{-1}$ at $20^{\circ} \mathrm{C}$ ) to avoid the formation of hyphal aggregates and compacted pellets, which tend to form in streptomycete liquid cultures even with shaking. Branched-chain amino acids were added to the medium at concentrations of 10,5 or $3.33 \mathrm{mM}$ according to whether one, two or all three amino acids were present. All experiments employed $100 \mathrm{ml}$ media in $500 \mathrm{ml}$ Erlenmeyer flasks containing $12 \mathrm{~g}$ glass beads ( $\mathrm{BDH}, 2 \cdot 5-3.5 \mathrm{~mm}$ diameter). Growth was monitored by measuring $\mathrm{OD}_{640}$; the optimal apparent doubling times were $2 \cdot 6-3 \cdot 2 \mathrm{~h}$.

Cultures were harvested at $\mathrm{OD}_{640} 1 \cdot 2-1 \cdot 3$, reached $20-26 \mathrm{~h}$ after inoculation. Immediately before cultures were harvested, $100 \mathrm{U}$ Penicillium funiculosum cellulase (EC 3.1.2.4) (Sigma) was added to remove the CMC from the mycelium, which could then be harvested by centrifugation and washed. It was resuspended in buffer $\left(100 \mathrm{mM}\right.$ potassium phosphate, $1 \cdot 2 \mu \mathrm{M} \mathrm{Na}{ }_{2}$ EDTA, $0 \cdot 2 \mu \mathrm{M}$ pyridoxal 5 -phosphate, $\mathrm{pH} 7 \cdot 5$ ) and disrupted at $0{ }^{\circ} \mathrm{C}$ by 
eight $15 \mathrm{~s}$ pulses from an MSE $100 \mathrm{~W}$ ultrasonic disintegrator at maximum amplitude, separated by $10 \mathrm{~s}$ intervals. The resulting mycelial extracts were clarified by low-speed centrifugation. Dialysis, when performed, was against a 100 -fold excess of the same buffer at $4{ }^{\circ} \mathrm{C}$ for $3 \mathrm{~h}$ or less.

Isolation of 4-azaleucine-resistant mutants. $S$. coelicolor D132 spores were plated $\left(5 \times 10^{7}\right.$ per plate) on minimal medium (as above, but without $\mathrm{CMC}$ ) containing 4-azaleucine (Sigma) at concentrations of 0.625 to $5 \mathrm{mg} \mathrm{ml}^{-1}$. Colonies developed at frequencies from $5.6 \times 10^{-6}$ (at $0.625 \mathrm{mg} \mathrm{ml}^{-1}$ ) to $4 \times 10^{-8}$ (at $5 \mathrm{mg} \mathrm{ml}^{-1}$ ) per spore. They were picked from the selective plate to R5 plates (Hopwood et al., 1985) and allowed to sporulate. Colonies showing good sporulation were transferred back to minimal medium with azaleucine at the concentration used for their initial selection; those retaining azaleucine resistance were replated on R5 and spore stocks were made. The isolates described below were grown in liquid minimal medium as described for the parent D132.

Enzyme and protein assays. AHAS and IPMS were assayed by the methods of Schloss \& Van Dyk (1988) (fixed time assay) and Kohlhaw (1988) respectively. Specific activities were expressed in units (mg protein) $)^{-1}$. One unit of AHAS activity is defined as the amount of enzyme that catalyses the formation of $1 \mu \mathrm{mol}$ acetolactate from pyruvate $\mathrm{min}^{-1}$; one unit of IPMS activity is the amount of enzyme catalysing the formation of $1 \mu \mathrm{mol} \mathrm{CoA}$ $\min ^{-1}$. Protein was assayed by the method of Bradford (1976).

\section{RESULTS}

\section{AHAS and IPMS activities in S. coelicolor grown with various combinations of leucine, isoleucine and valine}

S. coelicolor D132 was grown in minimal salts-glucose medium either unsupplemented or supplemented with one, two or all three of leucine, isoleucine and valine. Mycelia were washed and subjected to ultrasonic disintegration; the resulting extracts were clarified by centrifugation and used to determine the specific activities of AHAS and IPMS (Table 1). Similar results were obtained whether or not the extracts were dialysed before assay,

For AHAS, mediating the first common step in the isoleucine-valine pathway, the combination of all three amino acids gave in individual experiments activities $0 \cdot 12-0 \cdot 19$ of those with no supplementation, the ratio of the means being $0 \cdot 16$. Supplementation with threonine, or with leucine, isoleucine or valine singly or in pairwise combinations, gave no difference in specific activities when $95 \%$ confidence limits of the means were compared (Table 1). However, we noted a tendency for activities within individual experiments to rise above or fall below the mean in a consistent way. In all four experiments, the ratio of activities in the isoleucine-supplemented to the unsupplemented culture was above 1.5 , suggesting a slight but reproducible effect of isoleucine in enhancing AHAS activity.

The picture for IPMS, mediating the first specific step in the leucine biosynthesis pathway, was (perhaps surprisingly) similar. Once again, the combination of all three amino acids produced a significant fall in activities, which in individual experiments were $0 \cdot 14 \cdot 0 \cdot 17$ of those with no supplementation, the ratio of the means being $0 \cdot 21$. As with AHAS, although comparison of $95 \%$ confidence limits of the means suggested that supplementation with threonine, or with leucine, isoleucine or valine singly or in pairwise combinations, gave no difference in specific activities, additional effects were noted for all five sets of experiments in which IPMS was assayed. As for AHAS, isoleucine-supplemented cultures showed higher enzyme activities than unsupplemented ones, the ratios here varying from 1.8 to 8.3 ; in this case, a similar effect was apparent for cultures supplemented with isoleucine + valine (ratios of 1/7-3.4). Conversely, leucine on its own or in combination with either isoleucine or valine always gave a lower IPMS activity than the unsupplemented culture, the ratios being $0.47-0.86$ for leucine

Table 1. Effect of exogenous supplementation of S. coelicolor cultures with branchedchain amino acids on specific activities of AHAS and IPMS in mycelial extracts

\begin{tabular}{|c|c|c|c|c|}
\hline \multirow{2}{*}{$\begin{array}{l}\text { Amino acid } \\
\text { supplement }\end{array}$} & \multicolumn{2}{|c|}{ AHAS } & \multicolumn{2}{|c|}{ IPMS } \\
\hline & Units $\mathrm{mg}^{-1 *}$ & Ratio $\nmid$ & Units $\mathbf{m g}^{-1} \ddagger$ & Ratiof \\
\hline None & $3 \cdot 2 \pm 1 \cdot 6$ & - & $13 \pm 7 \cdot 4$ & - \\
\hline Threonine & $3 \cdot 1 \pm 1 \cdot 3$ & $0 \cdot 98$ & $23 \pm 8 \cdot 5$ & $1 \cdot 8$ \\
\hline Leucine & $3.7 \pm 1.5$ & $1 \cdot 2$ & $8 \cdot 9 \pm 2 \cdot 1$ & $0 \cdot 70$ \\
\hline Isoleucine & $6 \cdot 0 \pm 2 \cdot 5$ & 1.9 & $41 \pm 13$ & $3 \cdot 2$ \\
\hline Valine & $4 \cdot 3 \pm 2 \cdot 2$ & $1 \cdot 4$ & $16 \pm 5 \cdot 1$ & $1 \cdot 3$ \\
\hline Leucine + isoleucine & $3 \cdot 5 \pm 2 \cdot 4$ & $1 \cdot 1$ & $5 \cdot 0 \pm 3 \cdot 6$ & 0.4 \\
\hline Leucine + valine & $2 \cdot 1 \pm 1 \cdot 5$ & 0.67 & $7 \cdot 6 \pm 3 \cdot 5$ & 0.6 \\
\hline Isoleucine + valine & $4 \cdot 1 \pm 1 \cdot 9$ & $1 \cdot 3$ & $29 \pm 11$ & $2 \cdot 3$ \\
\hline Leucine + isoleucine + valine & $0 \cdot 51 \pm 0 \cdot 30$ & $0 \cdot 16$ & $2 \cdot 6 \pm 1 \cdot 1$ & $0 \cdot 21$ \\
\hline
\end{tabular}

* Figures represent the mean of four independent experiments, $\pm 95 \%$ confidence limits.

† Ratio of mean with the indicated supplement(s) to mean for the unsupplemented culture.

$\ddagger$ Figures represent the mean of five independent experiments, $\pm 95 \%$ confidence limits. 
Table 2. Effect of branched-chain amino acids on activities of AHAS and IPMS in dialysed $S$. coelicolor extracts

\begin{tabular}{|c|c|c|c|}
\hline Amino $\operatorname{acid}(\mathrm{s})$ & $\begin{array}{c}\text { Concn } \\
(\mathrm{mM})\end{array}$ & $\begin{array}{l}\text { AHAS } \\
\text { activity } \\
\text { (ratio } \\
\text { relative to } \\
\text { control) }\end{array}$ & $\begin{array}{l}\text { IPMS } \\
\text { activity } \\
\text { (ratio } \\
\text { relative to } \\
\text { control) }\end{array}$ \\
\hline Leucine & $\begin{array}{r}1 \\
5 \\
10\end{array}$ & $\begin{array}{l}0.73 \\
0.73 \\
0.69\end{array}$ & $\begin{array}{l}1 \cdot 10 \\
0 \cdot 17 \\
0 \cdot 08\end{array}$ \\
\hline Isoleucine & $\begin{array}{r}1 \\
5 \\
10\end{array}$ & $\begin{array}{l}0.95 \\
0.88 \\
0.86\end{array}$ & $\begin{array}{l}0.98 \\
0.97 \\
1.20\end{array}$ \\
\hline Valine & $\begin{array}{r}1 \\
5 \\
10\end{array}$ & $\begin{array}{l}1 \cdot 40 \\
1 \cdot 20 \\
1 \cdot 30\end{array}$ & $\begin{array}{l}1 \cdot 10 \\
0 \cdot 96 \\
1 \cdot 10\end{array}$ \\
\hline Leucine + isoleucine + valine & $\begin{array}{r}1^{*} \\
5^{*} \\
10^{*}\end{array}$ & $\begin{array}{l}1 \cdot 20 \\
0.99 \\
1.50\end{array}$ & $\begin{array}{l}0.95 \\
0.59 \\
0.21\end{array}$ \\
\hline
\end{tabular}

* This represents the total amino acid concentration; the concentration of each individual amino acid was therefore one-third of this.

alone, $0 \cdot 18-0 \cdot 53$ for leucine + isoleucine, and $0 \cdot 47-0 \cdot 91$ for leucine + valine.

Specific activities estimated in this way as an indication of comparative levels of gene transcription are subject to many provisos, one of which is that feedback effects on enzyme activity may be playing a role. To examine this possibility, cultures were grown without branched-chain amino acid supplementation, in the expectation of removing any amino acids bound to the enzymes. Mycelial extracts were assayed in reaction mixtures lacking leucine, isoleucine or valine, and with these amino acids, singly or in triple combination, at concentrations of 1,5 or $10 \mathrm{mM}$. The results (Table 2) show a major effect only in the inhibition of IPMS activity by leucine (somewhat reduced when all three amino acids are present). Inhibition of IPMS by leucine has been reported previously for Nocardia opaca, a species related to the streptomycetes (Stieglitz \& Calvo, 1974). The only values in Table 1 that could be affected by the data in Table 2 are those involving IPMS and leucine-grown cultures. However, Table 1 shows that the specific activity of IPMS is more strongly diminished during growth with all three amino acids present than with leucine alone or with one other amino acid. Table 2 shows conversely that the specific activity of IPMS is less strongly diminished when all three amino acids are present than in the presence of leucine alone or with one other amino acid. We conclude that the effect of all three amino acids during growth is unlikely to be explained solely by the presence of leucine in the assayed extract, though this is not conclusive because of uncertainties in, for example, the intracellular amino acid concentrations.
Table 3. Effect of limiting supplementation with isoleucine or valine in cultures of the $S$. coelicolor ilv mutant 966 on specific activities of AHAS and IPMS in mycelial extracts

Phenylalanine was in all cases present in excess $(0.5 \mathrm{mM})$.

\begin{tabular}{|c|c|c|c|}
\hline $\begin{array}{l}\text { Isoleucine } \\
\text { concn } \\
(\mu \mathrm{M})\end{array}$ & $\begin{array}{c}\text { Valine } \\
\text { concn } \\
(\mu \mathrm{M})\end{array}$ & $\begin{array}{c}\text { AHAS } \\
\text { (units } \mathrm{mg}^{-1} \text { ) }\end{array}$ & $\begin{array}{c}\text { IPMS } \\
\text { (units } \mathrm{mg}^{-1} \text { ) }\end{array}$ \\
\hline 100 & 100 & $2 \cdot 3$ & 2.5 \\
\hline 75 & 75 & 4.7 & $2 \cdot 1$ \\
\hline 50 & 50 & 13 & $3 \cdot 6$ \\
\hline 25 & 25 & 10 & $1 \cdot 1$ \\
\hline 100 & 100 & 1.7 & $3 \cdot 4$ \\
\hline 75 & 100 & 2.5 & $2 \cdot 4$ \\
\hline 50 & 100 & $4 \cdot 1$ & $2 \cdot 2$ \\
\hline 25 & 100 & 11 & $0 \cdot 4$ \\
\hline 100 & 100 & $1 \cdot 4$ & $2 \cdot 0$ \\
\hline 100 & 75 & $1 \cdot 2$ & $1 \cdot 2$ \\
\hline 100 & 50 & $1 \cdot 8$ & $2 \cdot 4$ \\
\hline 100 & 25 & 1.5 & $3 \cdot 2$ \\
\hline
\end{tabular}

\section{AHAS and IPMS activities in isoleucine-valine auxotrophs grown with limiting isoleucine/valine}

When a bacterial amino acid auxotroph is grown with a limiting concentration of the required amino acid, it is often found that during the brief period between exhaustion of the amino acid and complete cessation of protein synthesis, enzyme activities in the biosynthetic pathway for that amino acid become very high. This is due to loss of end-product control of expression of genes encoding the biosynthetic enzymes when the internal level of the amino acid becomes insufficient for end-product control. We have carried out similar experiments with auxotrophs of $S$. coelicolor, to determine whether such a rise in biosynthetic enzyme levels occurs for these auxotrophs; if it does, it is likely that some form of end-product control exists. We have found with arginine auxotrophs (Soutar \& Baumberg, 1996) that the arginine biosynthetic enzyme ornithine carbamoyltransferase can show an approximately 100 -fold increase in specific activity.

Experiments of this type were carried out with $S$. coelicolor A3(2) strain 966, which requires isoleucine + valine and phenylalanine. We have noted that there is a difference in certain aspects of growth with a limiting amino acid between Escherichia coli/Salmonella typhimurium and those $S$. coelicolor auxotrophs we have so far tested, in particular strains 966 and 2281, an arginine auxotroph (Soutar \& Baumberg, 1996). An enterobacterial auxotroph generally grows at the same rate with limiting as with sufficient amino acid until just before amino acid exhaustion, at which point growth either ceases completely or, if the mutant is 'leaky', continues at the new slower rate. Our growth experiments (results not shown) indicate that for an $S$. colicolor auxotroph, as the initial concentration of the limiting amino acid is decreased, the lag prior to 
Table 4. AHAS and IPMS specific activities in 4-azaleucine-resistant mutants of $S$. coelicolor grown without amino acid supplement, or supplemented with isoleucine or leucine + isoleucine + valine

\begin{tabular}{|c|c|c|c|c|c|}
\hline \multirow[t]{2}{*}{ Mutant } & \multirow[t]{2}{*}{ Supplement } & \multicolumn{2}{|c|}{ AHAS } & \multicolumn{2}{|c|}{ IPMS } \\
\hline & & Units $\mathrm{mg}^{-1 *}$ & Ratio $†$ & Units $\mathrm{mg}^{-1 *}$ & Ratio $†$ \\
\hline \multirow[t]{3}{*}{1} & None & 0.7 & - & 11 & - \\
\hline & Isoleucine & $0 \cdot 9$ & $1 \cdot 4$ & $42 \cdot 5$ & 3.9 \\
\hline & $\begin{array}{l}\text { Leucine }+ \text { isoleucine } \\
\text { + valine }\end{array}$ & $0 \cdot 1$ & $0 \cdot 2$ & $2 \cdot 8$ & $0 \cdot 3$ \\
\hline \multirow[t]{3}{*}{3} & None & $9 \cdot 4$ & - & 61 & - \\
\hline & Isoleucine & 16 & $1 \cdot 7$ & 40 & 0.7 \\
\hline & $\begin{array}{l}\text { Leucine + isoleucine } \\
\text { + valine }\end{array}$ & $2 \cdot 7$ & $0 \cdot 3$ & 77 & $1 \cdot 3$ \\
\hline \multirow[t]{3}{*}{7} & None & 11 & - & 53 & - \\
\hline & Isoleucine & $13 \cdot 5$ & $1 \cdot 2$ & 83 & $1 \cdot 6$ \\
\hline & $\begin{array}{l}\text { Leucine }+ \text { isoleucine } \\
+ \text { valine }\end{array}$ & $1 \cdot 2$ & $0 \cdot 1$ & 45 & $0 \cdot 9$ \\
\hline \multirow[t]{3}{*}{9} & None & 0.5 & - & $2 \cdot 5$ & - \\
\hline & Isoleucine & $1 \cdot 0$ & $1 \cdot 8$ & $12 \cdot 5$ & $5 \cdot 1$ \\
\hline & $\begin{array}{l}\text { Leucine + isoleucine } \\
\text { + valine }\end{array}$ & $1 \cdot 0$ & $1 \cdot 8$ & $1 \cdot 1$ & $0 \cdot 4$ \\
\hline \multirow[t]{3}{*}{10} & None & $4 \cdot 6$ & - & 98 & - \\
\hline & Isoleucine & $9 \cdot 7$ & $2 \cdot 1$ & 69 & $0 \cdot 7$ \\
\hline & $\begin{array}{l}\text { Leucine + isoleucine } \\
\text { + valine }\end{array}$ & $0 \cdot 6$ & $0 \cdot 1$ & 67 & $0 \cdot 7$ \\
\hline \multirow[t]{3}{*}{11} & None & $0 \cdot 6$ & - & $2 \cdot 9$ & - \\
\hline & Isoleucine & 0.8 & $1 \cdot 2$ & 31 & 11 \\
\hline & $\begin{array}{l}\text { Leucine + isoleucine } \\
\text { + valine }\end{array}$ & $0 \cdot 1$ & $0 \cdot 2$ & $2 \cdot 3$ & $0 \cdot 8$ \\
\hline \multirow[t]{3}{*}{12} & None & 0.9 & - & 21 & - \\
\hline & Isoleucine & $1 \cdot 3$ & $1 \cdot 4$ & $5 \cdot 7$ & $0 \cdot 3$ \\
\hline & $\begin{array}{l}\text { Leucine }+ \text { isoleucine } \\
\text { + valine }\end{array}$ & $0 \cdot 1$ & $0 \cdot 1$ & $2 \cdot 7$ & $0 \cdot 1$ \\
\hline
\end{tabular}

* Figures represent the mean of two independent experiments.

† Relative to unsupplemented culture.

growth increases and the subsequent growth rate decreases. There does not seem to be the discontinuity in growth that is characteristic of enterobacterial auxotrophs. We do not however believe that these differences invalidate the interpretation of such experiments. S. coelicolor strain 966 was grown in minimal salts-glucose media supplemented with various concentrations of isoleucine and valine, and with phenylalanine always in excess $(0.5 \mathrm{mM})$. AHAS and IPMS activities were measured in mycelium harvested at approximately $48 \mathrm{~h}$. Results are shown in Table 3. At isoleucine concentrations below 50-75 $\mu \mathrm{M}$ (variable in different experiments), an appreciable increase in AHAS specific activity is observed, to a maximum of 13 units $\mathrm{mg}^{-1}$. No effect was found at the same valine concentrations. IPMS served to some extent as a control, in that Table 3 shows no consistent increase in IPMS activity with limitation of either amino acid, suggesting that the effect on AHAS is not general for amino acid biosynthetic enzymes. This is also implied by the fact that an arginine auxotroph, grown similarly in limiting concentrations of arginine, shows strong derepression for the arginine biosynthetic enzyme ornithine carbamoyltransferase (Soutar \& Baumberg, 1996), but not for AHAS or IPMS (results not shown). Similar though less complete results (not shown) to those with strain 966 have also been obtained with S. coelicolor 1044 , an isoleucine auxotroph also from the John Innes Institute collection.

\section{AHAS and IPMS activities in 4-azaleucine-resistant mutants grown with various combinations of leucine, isoleucine and valine}

In the enterobacteria and other prokaryotes, mutants resistant to amino acid analogues have often lost endproduct control of either enzyme activity or synthesis; as 
a result, the internal pool size of the specific amino acid(s) increases so that the toxic analogue is out-competed. For instance, in E. coli, S. typhimurium and Bacillus subtilis, mutants resistant to leucine analogues may be obtained that are defective in control by leucine of the leu operon - and, in B. subtilis, of ilv genes as well (see reviews by Umbarger, 1987, and Fink, 1993). To examine whether analogous mutants could be obtained in $S$. coelicolor, we plated spores of D132 on minimal medium containing 4azaleucine (see Methods). Seven of the resistant colonies purified were grown in minimal medium alone, supplemented with isoleucine or supplemented with all three branched-chain amino acids. Assays for AHAS and IPMS activity are shown in Table 4. Four types of mutant with distinct patterns of enzyme activity could be discerned. Type 1, exemplified by nos 1 and 11, showed AHAS activities similar to the wild-type (see Table 1) under all three conditions; and IPMS activities about 3- to 4-fold higher in the presence of isoleucine, and about 2-fold higher in cultures with no supplementation or with all three amino acids. Type 2 , exemplified by no. 12, showed the same AHAS activities as the wild-type; the IPMS activity with no supplementation was about 3-fold higher than wild-type, and when supplemented with isoleucine alone or together with leucine and valine, 2- to 3-fold lower than wild-type. Type 3, exemplified by no. 9, showed AHAS activities similar to wild-type except in the presence of all three branched-chain amino acids, where the activity was similar to that in the presence of isoleucine alone. IPMS activities in Type 3 were 1.5 - to 3 -fold lower than wild-type, except in the presence of all three branched-chain amino acids, where the activity was similar to that of the wild-type. Type 4 , exemplified by the remaining three isolates, nos 3, 7 and 10, showed a similar enzyme level phenotype: AHAS activities were increased over the wild-type by factors of 3 to 7 , depending on the supplementation (or lack of it) and the isolate, though the ratios between activities under the three conditions tested remained much as in the wild-type; IPMS activities were 6- to 15-fold higher than in the wild-type, in this case with no apparent correlation with the growth medium.

\section{DISCUSSION}

We present in this paper data consistent with the existence of quantitatively significant systems regulating the production of at least one enzyme each of the isoleucinevaline and leucine biosynthetic pathways in S. coelicolor. In batch culture in minimal media supplemented with none, one, two or three of these amino acids, AHAS showed an approximately 10 -fold and IPMS an approximately 15 fold difference between the highest and lowest specific activities obtained with isoleucine or leucine + isoleucine + valine supplementation respectively. The most pronounced effects of adding various possible combinations of branched-chain amino acids to minimal medium were a 5 - to 8 -fold depression in specific activity when all three amino acids were supplied, and a 1.5- to 3 fold stimulation when isoleucine or isoleucine + valine were supplied. These effects - particularly the formercontrast markedly with those reported by Vančura $e t$ al.
(1989) for Streptomyces fradiae, where AHAS activities showed modest (up to $2 \cdot 5$-fold) stimulation by valine alone, valine + leucine, or valine + leucine + isoleucine. The effects of the branched-chain amino acids when added to assay mixtures following dialysis of protein extracts did not allow an explanation of these results in terms simply of activation or inhibition of the enzymes by amino acids remaining in the protein extracts used, although we were able to show that, as for instance in the enterobacteria (Umbarger, 1987), B. subtilis (Ward \& Zahler, 1973) and Corynebacterium glutamicum (Patek et al., 1994), IPMS is subject to feedback inhibition by leucine. Two further experiments provided evidence for specific end-product control of expression of the genes encoding these two enzymes. First, growth of isoleucine auxotrophs with limiting concentrations of isoleucine increased AHAS activities, while having little or no effect on IPMS activities, or on the activity of an enzyme from an unconnected pathway (the ornithine carbamoyltransferase of arginine biosynthesis). Second, 4-azaleucine-resistant mutants showed at least four distinct phenotypes, in terms of AHAS and IPMS activities, under different conditions of supplementation; the maximum specific activities among these isolates were, for both enzymes, of the order of 100 times higher than the lowest activities found for the wild-type, which-again for both enzymes - were obtained with supplementation of minimal medium with all three amino acids. We infer that regulatory systems must exist, capable of providing this range of expression, for genes encoding biosynthetic enzymes for these amino acids.

In both the isoleucine-valine and leucine pathways of enterobacteria, attenuation is of major importance in endproduct regulation at the level of gene expression, although activation, repression and the global regulator Lrp also play a role (Umbarger $e t$ al., 1987; Newman $e t$ al., 1992; Calvo \& Matthews, 1994). The situation is complicated by the existence of three different AHAS isoenzymes, each made up of two distinct subunits; the subunits are encoded by contiguous pairs of genes, each pair showing different control features. In B. subtilis, on the other hand, it appears that regulation in these systems is by a termination-antitermination mechanism involving alternative leader mRNA secondary structures but not a translatable leader peptide (Grandoni et al., 1993). This is known also to be the case for the trp biosynthesis gene cluster in this organism, control being exerted through the RNA-binding MtrB protein (Babitzke \& Yanofsky, 1993; Gollnick, 1994). However, in the ilv-leu system the effector is probably uncharged tRNA (Henkin, 1994). In C. glutamicum, a region upstream of the leu $A$ gene is capable of forming alternative secondary structures in the mRNA, within which lies a translatable sequence; the combination suggests an enterobacteria-like attenuation system (Patek et al., 1994). In this organism the ilvBNC operon appeared to be associated with three active promoters (Keilhauer et al., 1993).

It seems possible that in streptomycetes also attenuation acts in these systems. De Rossi et al. (1995) have obtained the sequence of an ilvBNC gene cluster from S. avermitilis; 
they find upstream of $i l v B$ a leader sequence translatable into a 13 -amino-acid peptide containing four consecutive codons for branched chain amino acids (Ile-Leu-Val-Leu), characteristic of attenuation control. In addition, we have found (unpublished results) for the leu $A$ gene of $S$. rochei previously cloned in our laboratory (Hercombet al., 1987) a similar set of four Leu codons preceding the gene. Further work will be needed to establish whether attenuation alone is sufficient to provide the complex enzyme phenotypes shown in Tables 1 and 4. The 4azaleucine-resistant mutants of types 1 and 2 , being wildtype for AHAS under the conditions tested, could well carry cis-acting mutations affecting attenuation upstream of a leu gene or operon. Since mutants of types 3 and 4 are affected in both AHAS and IPMS, they seem at first sight to have mutations in a trans-acting gene(s), since there is no genetic data suggesting that in $S$. coelicolor, ilv and leu genes form an operon as they do in B. subtilis (Fink, 1993; Grandoni et al., 1992). Mapping of ilv-leu mutations in $S$. coelicolor is incomplete, and the region at about 5 o'clock on the $S$. coelicolor genetic map (Hopwood et al., 1985) could contain an ilv-leu operon as in B. subtilis (Fink, 1993; Grandoni et al., 1992). It is also possible that the 4azaleucine-resistant mutants contain multiple mutations. Finally, the pattern of activities shown in Table 1 obviously differs greatly from that described in similar experiments with $S$. fradiae by Vančura et al. (1989). It will clearly be of great interest to establish whether there is a correlation between the regulatory phenotype for branched-chain amino acid biosynthesis and the use of these amino acids for secondary metabolite production.

\section{ACKNOWLEDGEMENTS}

We acknowledge stimulating and valuable discussions with Drs David A. Hodgson and Charlotte West, and the provision of strains by members of the John Innes Institute. This work is funded by a grant from the (then) Biotechnology - now Chemicals and Pharmaceuticals - Directorate of the BBSRC to S.B. and D.A.H.

\section{REFERENCES}

Babitzke, P. \& Yanofsky, C. (1993). Reconstitution of Bacillis subtilis trp attenuation in vitro with TRAP, the trp RNA-binding attenuation protein. Proc Natl Acad Sci US A 90, 133-137.

Bradford, M. M. (1976). A rapid and sensitive method for the quantitation of microgram quantities of protein utilising the principle of protein-dye binding. Anal Biocbem 72, 248-254.

Calvo, J. M. \& Matthews, R. G. (1994). The leucine-responsive regulatory protein, a global regulator of metabolism in Escherichia coli. Microbiol Rev' 58, 466-490.

Castelli, P., Donadio, S., Marinelli, F., Borghi, A. \& Sosio, M. (1995). Complementation of a Streptomyces lividans $\mathrm{Leu}^{-}$mutant by the Actinoplanes teichomyceticus leuC gene. Gene 158, 97-100.

De Rossi, E., Leva, R., Gusberti, L., Manachini, P. L. \& Riccardi, G. (1995). Cloning, sequence and expression of the ilvBNC gene cluster from Streptomyces avermitilis. EMBL database accession no. L39268.

Denoya, C. D., Fedechko, R. W., Hafner, E. W., McArthur, H. A. I., Morgenstern, M. R., Skinner, D. D., Stutzman-Engwall, K., Wax, R. G. \& Wernau, W. C. (1995). A second branched-chain $\alpha$-keto acid dehydrogenase gene cluster (bkdFGH) from Streptomyces avermitilis: its relationship to avermectin biosynthesis and the construction of a $b k d F$ mutant suitable for the production of novel antiparasitic avermectins. J Bacteriol 177, 3504-3511.

Doull, J. L. \& Vining, L. C. (1989). Culture conditions promoting dispersed growth and biphasic production of actinorhodin in shaken cultures of Streptomyces coelicolor A3(2). FEMS Microbiol Lett 65, 265-268.

Fink, P. S. (1993). Biosynthesis of the branched-chain amino acids. In Bacillus subtilis: the Model Gram-positive Organism, pp. 307-317. Edited by A. Sonenshein, J. A. Hoch \& R. Losick. Washington, DC: American Society for Microbiology.

Gollnick, P. (1994). Regulation of the Bacillus subtilis trp operon by an RNA-binding protein. Mol Microbiol 11, 991-997.

Grandoni, J. A., Zahler, S. A. \& Calvo, J. M. (1992). Transcriptional regulation of the ilv-leu operon of Bacillus subtilis. J Bacteriol 174, 3212-3219.

Grandoni, J. A., Fulmer, S. B., Brizzio, V., Zahler, S. A. \& Calvo, J. M. (1993). Regions of the Bacillus subtilis ilv-leu operon involved in regulation by leucine. $J$ Bacteriol 175, 7581-7593.

Henkin, T. M. (1994). Transfer-RNA-directed transcription antitermination. Mol Microbiol 13, 381-387.

Hercomb, J., Thierbach, G., Baumberg, S. \& Parish, J. H. (1987). Cloning, characterization and expression in Eschericbia coli of a leucine biosynthetic gene from Streptomyces rocbei. J Gen Microbiol 133, 317-322.

Hood, D. W., Heidstra, R., Swoboda, U. K. \& Hodgson, D. A. (1992). Molecular genetic analysis of proline and tryptophan biosynthesis in Streptomyces coelicolor A3(2): interaction between primary and secondary metabolism - a review. Gene 115, 5-12.

Hopwood, D. A. \& Khosla, C. (1992). Genes for polyketide secondary metabolic pathways in microorganisms and plants. In Secondary Metabolites: Their Function and Evolution (Ciba Foundation Symposium 171), pp. 88-112. Edited by D. J. Chadwick \& J. Whelan. Chichester: John Wiley.

Hopwood, D. A., Bibb, M. J., Chater, K. F., Kieser, T., Bruton, C. J., Kieser, H. M., Lydiate, D. J., Smith, C. P., Ward, J. M. \& Schrempf, H. (1985). Genetic Manipulation of Streptomyces: a Laboratory Manual. Norwich: John Innes Foundation.

Hutchinson, C. R. \& Fujii, I. (1995). Polyketide synthase gene manipulation: a structure-function approach in engineering novel antibiotics. Annu Rev Microbiol 49, 201-238.

Hutchinson, C. R., Decker, H., Madduri, K., Otten, S. L. \& Tang, L. (1993). Genetic control of polyketide biosynthesis in the genus Streptomyces. Antonie Leeunenboek 64, 165-176.

Katz, L. \& Donadio, S. (1993). Polyketide synthesis: prospects for hybrid antibiotics. Annu Rev Microbiol 47, 875-912.

Keilhauer, C., Eggeling, L. \& Sahm, H. (1993). Isoleucine synthesis in Coryebacterium glutamicum - molecular analysis of the ilvB-ilvNilv C operon. J Bacteriol 175, 5595-5603.

Kohlhaw, G. B. (1988). $\alpha$-Isopropylmalate synthase from yeast. Methods Enzymol 166, 414-423.

Lounès, A., Lebrihi, A., Benslimane, C., Lefebvre, G. \& Germain, P. (1995). Regulation of valine catabolism by ammonium in Streptomyces ambofaciens, producer of spiramycin. Can J Microbiol 41, 800-808.

Newman, E. B., D'Ari, R. \& Lin, R. T. (1992). The leucine-Lrp regulon in Escherichia coli - a global response in search of a raison d'être. Cell 68, 617-619.

Nguyen, L. T., Nguyen, K. T., Spizek, J. \& Běhal, V. (1995). The tylosin producer, Streptomyces fradiae, contains a second valine dehydrogenase. Microbiology 141, 1139-1145. 
Patek, M., Krumbach, K., Eggeling, L. \& Sahm, H. (1994). Leucine synthesis in Corynebacterium glutamicum - enzyme activities, structure of $\operatorname{leu} A$, and effect of $\operatorname{leu} A$ inactivation on lysine synthesis. Appl Environ Microbiol 60, 133-140.

Reynolds, K. A., O'Hagan, D., Gani, D. \& Robinson, J. A. (1988). Butyrate metabolism in streptomycetes. Characterization of an intramolecular vicinal interchange rearrangement linking isobutyrate and butyrate in Streptomyces cimnamonensis. J Chem Soc Perkin Trans 1, 3195-3207.

Soutar, A. \& Baumberg, S. (1996). Implication of a repression system, homologous to those of other bacteria, in the control of arginine biosynthesis genes in Streptomyces coelicolor. Mol Gen Genet (in press).

Schloss, J. V. \& Van Dyk, D. E. (1988). Acetolactate synthase isozyme II from Salmonella typhimurium. Methods Ensymol 166, 445-454.

Stieglitz, B. I. \& Calvo, J. M. (1974). Distribution of the isopropylmalate pathway to leucine among diverse bacteria. J Bacteriol 118, 935-941.

Tang, L. \& Hutchinson, C. R. (1993). Sequence, transcriptional, and functional analyses of the valine (branched-chain amino acid) dehydrogenase gene of Streptomyces coelicolor. I Bacteriol 175, 4176-4185.
Tang, L., Zhang, Y.-X. \& Hutchinson, C. R. (1994). Amino acid catabolism and antibiotic synthesis: valine is a source of precursors for macrolide biosynthesis in Streptomyces ambofaciens and Streptomyces fradiae. J Bacteriol 176, 6107-6119.

Umbarger, H. E. (1987). Biosynthesis of the branched-chain amino acids. In Eschericbia coli and Salmonella typhimurium: Cellular and Molecular Biology, pp. 352-367. Edited by F. C. Neidhardt, J. L. Ingraham, K. Brooks Low, B. Magasanik, M. H. Schaechter \& H. E. Umbarger. Washington, DC: American Society for Microbiology.

Vančura, A., Řezanka, T., Mař̌álek, J., Melzoch, K., Basǎ̛ová, G. \& KYrištan, V. (1988). Metabolism of L-threonine and fatty acids and tylosin biosynthesis in Streptomyces fradiae. FEMS Microbiol Lett 49, 411-415.

Vančura, A., Vančurová, I., Kopecký, J., Maršálek, J., Cikánek, D., Basařová, G. \& Krrištan, v. (1989). Regulation of branched-chain amino acid biosynthesis in Streptomyces fradiae, a producer of tylosin. Arch Microbiol 151, 537-540.

Ward, J. B., Jr \& Zahler, S. A. (1973). Regulation of leucine biosynthesis in Bacillus subtilis. J Bacteriol 116, 727-735.

Received 24 November 1995; revised 11 March 1996; accepted 28 March 1996. 